WATER QUALITY AND SUPPLY ON CORTINA RANCHERIA, COLUSA COUNTY, CALIFORNIA

By Eugene B. Yates

U.S. GEOLOGICAL SURVEY

Water-Resources Investigations Report 89-4004 
DEPARTMENT OF THE INTERIOR

MANUEL LUJAN, JR., Secretary

U.S. GEOLOGICAL SURVEY

Dallas L. Peck, Director

For additional information write to:

District Chief

U.S. Geological Survey

Federal Building, Room W-2234

2800 Cottage Way

Sacramento, CA 95825
Copies of this report may be purchased from:

U.S. Geological Survey Books and Open-File Reports Section Federal Center, Building 810

Box 25425

Denver, CO 80225 


\section{CONTENTS}

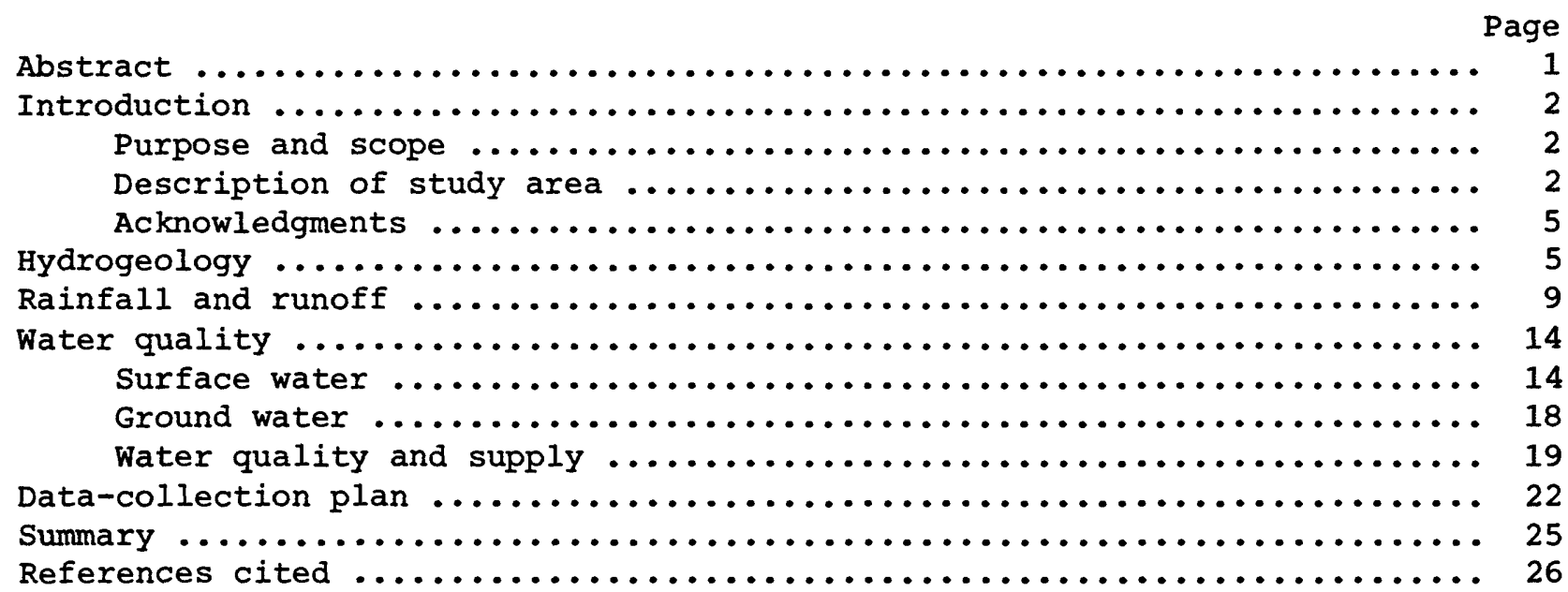

\section{ILLUSTRATIONS}

Figures 1-3. Maps showing:

1. Locations of Cortina Rancheria, stream-gaging stations, and rainfall stations used in

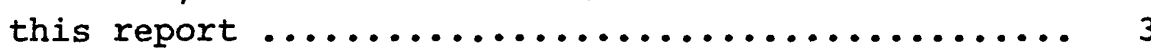

2. Topographic, hydrologic, and cultural features of Cortina Rancheria ...................... 4

3. Geologic map and section of Cortina Rancheria and vicinity

4-8. Graphs showing:

4. Relation between average annual runoff per unit area and average annual rainfall for selected drainage areas along the west side of the

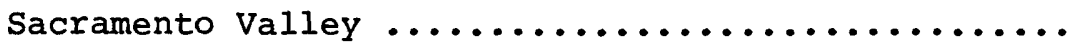

5. Dimensionless flow-duration curves for selected stream-gaging stations along the west side of the

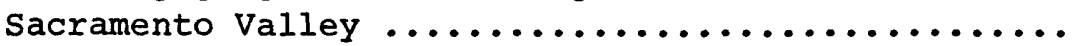

6. Relation between specific conductance and discharge

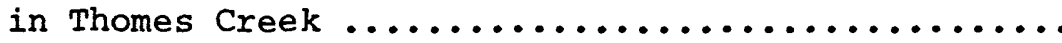

7. Relation between chloride concentration and

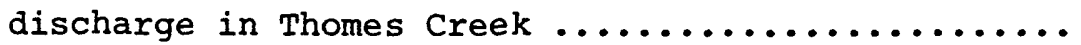

8. Discharge and specific conductance in Thomes Creek,

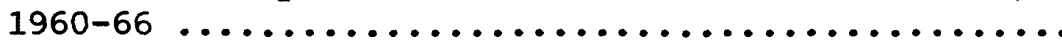
,

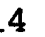

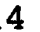
年

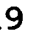

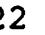
25 26 


\section{TABLES}

Table 1. Characteristics of selected streams along the west side

Page

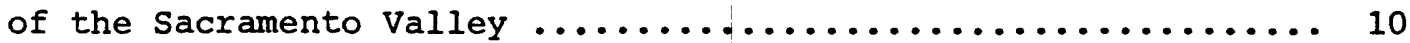

2. Water quality of selected streams along the west side of the Sacramento valley .......................... 14

3. Water-quality data for Cortina Rancheria and drinking-water

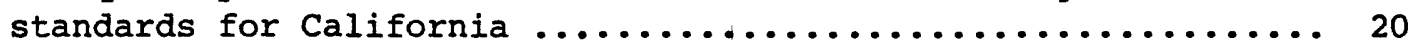

\section{CONVERSION FACTORS}

For use of readers who prefer to use metric and International System (SI) units rather than the inch-pound units used in this report, the following conversion factors may be used:

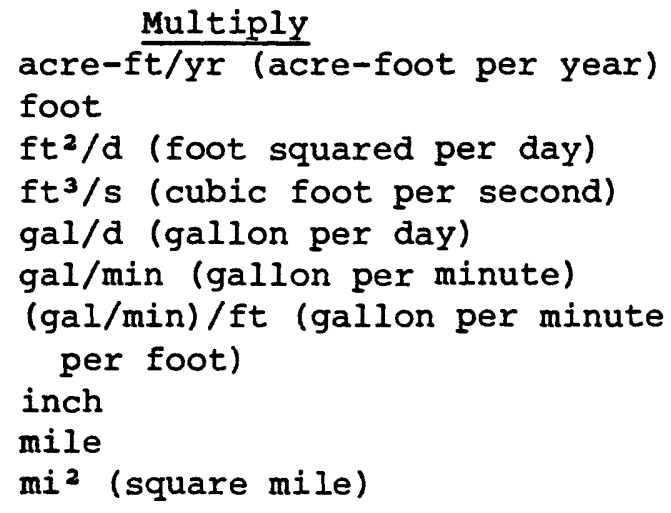

Multiply acre-ft/yr (acre-foot per year) foot

$\mathrm{ft}^{2} / \mathrm{d}$ (foot squared per day)

$\mathrm{ft}^{3} / \mathrm{s}$ (cubic foot per second) gal/d (gallon per day) gal/min (gallon per minute) (gal/min)/ft (gallon per minute per foot)

inch

mile

$\mathrm{mi}^{2}$ (square mile)

$$
\begin{gathered}
1,233 \quad \text { By } \\
0.3048 \\
0.09290 \\
0.02832 \\
0.003785 \\
0.06308 \\
0.2070
\end{gathered}
$$$$
25.4
$$$$
1.609
$$$$
259.0
$$

\section{DEFINITION OF TERMS}

\author{
To obtain \\ cubic meter per year \\ meter \\ meter squared per day \\ cubic meter per second \\ cubic meter per day \\ liter per second \\ liter per second \\ per meter \\ millimeter \\ kilometer \\ hectare
}

Water Year: A water year is a 12-month period, October 1 through September 30, designated by the calendar year in which it ends. In this report, years are water years unless otherwise noted.

Sea Level: In this report "sea level" refers to the National Geodetic Vertical Datum of 1929 (NGVD of 1929)--a geodetic datum derived from a general adjustment of the first-order level nets of both the United States and Canada, formerly called Sea Level Datum of 1929. 


\title{
WATER QUALITY AND SUPPLY ON CORTINA RANCHERIA, COLUSA COUNTY, CALIFORNIA
}

\author{
By Eugene B. Yates
}

\begin{abstract}
Cortina Rancheria covers an area of 1 square mile in Colusa County, California, near the western edge of the Sacramento Valley. Local sources of water for residents of the rancheria are of poor quality or limited availability. Domestic needs are presently met by water from a hand-dug well and from a drilled well with a potential yield of 15 gallons per minute. Water from both wells fails to meet California state drinking-water standards, primarily because of high concentrations of chloride and dissolved solids. High concentrations of sodium and boron pose additional problems for agricultural use of the water. The dissolved ions originate in Upper Cretaceous marine sediments of the Cortina Formation, which occurs at or near land surface throughout the rancheria. Small quantities of fresh ground water may occur locally in the Tehama Formation of Pliocene age, a thin layer of which overlies the Cortina Formation in the eastern part of the rancheria. Canyon Creek, the largest stream on the rancheria, has a drainage area of 3.1 square miles and flows only during winter and spring. Water from one of the rancheria's three springs meets drinking-water standards, but it flows at little more than a trickle during summer. The generally poor quality of ground and surface water on the rancheria is typical of areas along the west side of the Sacramento valley, as is indicated by statistical analysis of regional data. Local and seasonal variations in water quality, however, offer possibilities for improving the water supply by storing winter runoff or by developing local sources of better quality ground water.

Additional collection of hydrologic information could indicate more precisely the quantity and quality of surface and ground water on Cortina Rancheria. Principal features of a possible data-collection program would include monitoring of discharge and water quality in three springs and in Canyon Creek, electromagnetic terrain conductivity surveys, and monitoring of water levels and quality in two existing wells and several proposed test wells.
\end{abstract}




\section{INTRODUCTION}

Cortina Rancheria in Colusa County is located near the western edge of the Sacramento Valley in northern California. Two wells supply water to meet the domestic needs of rancheria residents. Local ground water is highly mineralized because of the presence of salts in exposed or near-surface marine sediments. Water from the two wells fails to meet State of California (1985) drinking-water standards because of high concentrations of chloride and dissolved solids. Most residents prefer to drink bottled water because of the oily feel and slightly sulfurous odor of the well water (Mary Norton, Cortina Wintun tribal chairperson, oral commun., 1987). Residential and economic development of the rancheria cannot be planned with certainty until the quantity and quality of locally available water supplies are determined.

\section{$\underline{\text { Purpose and Scope }}$}

The purpose of this report is to describe the quantity and quality of ground and surface water on Cortina Rancheria from data available at the time of the study and to describe a program of data collection designed to provide more accurate and detailed water-resources information. Flow duration of surface streams and quality of surface and ground water on Cortina Rancheria were inferred from statistical analyses of data from other streams along the west side of the Sacramento Valley. In addition, water samples from two wells and two springs were analyzed for major ions and selected trace elements. Water quality on the rancheria was evaluated for suitability as drinking or irrigation water.

\section{Description of Study Area}

Cortina Rancheria is located in Colusa County, about 13 miles west of the town of Arbuckle (fig. 1), in section 34 of T. 14 N., R. 4 W., Mount Diablo baseline and meridian. This $1-\mathrm{mi}^{2}$ area is located midway up the eastern slopes of Cortina Ridge, which marks the western edge of the Sacramento Valley. The terrain in the western half of the rancheria is steep and deeply dissected, but slopes in the eastern half are more gentle. Altitude ranges from 620 to about 1,700 feet above sea level (fig. 2). Oak trees and grass are the dominant vegetation on south-facing slopes; dense chaparral occurs on north-facing slopes. 


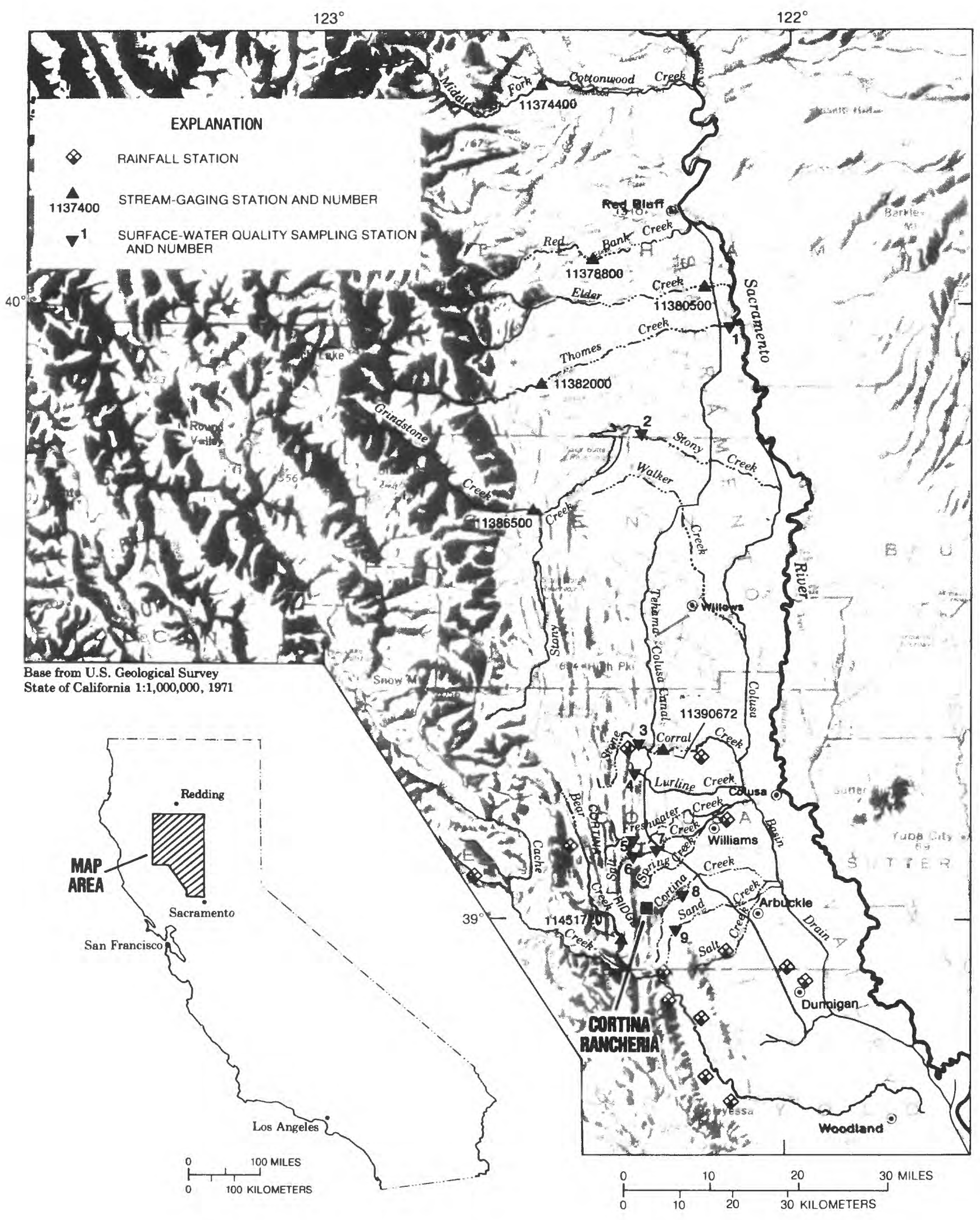

FIGURE 1. Locations of Cortina Rancheria, streamgaging stations, and rainfall stations used in this report. 


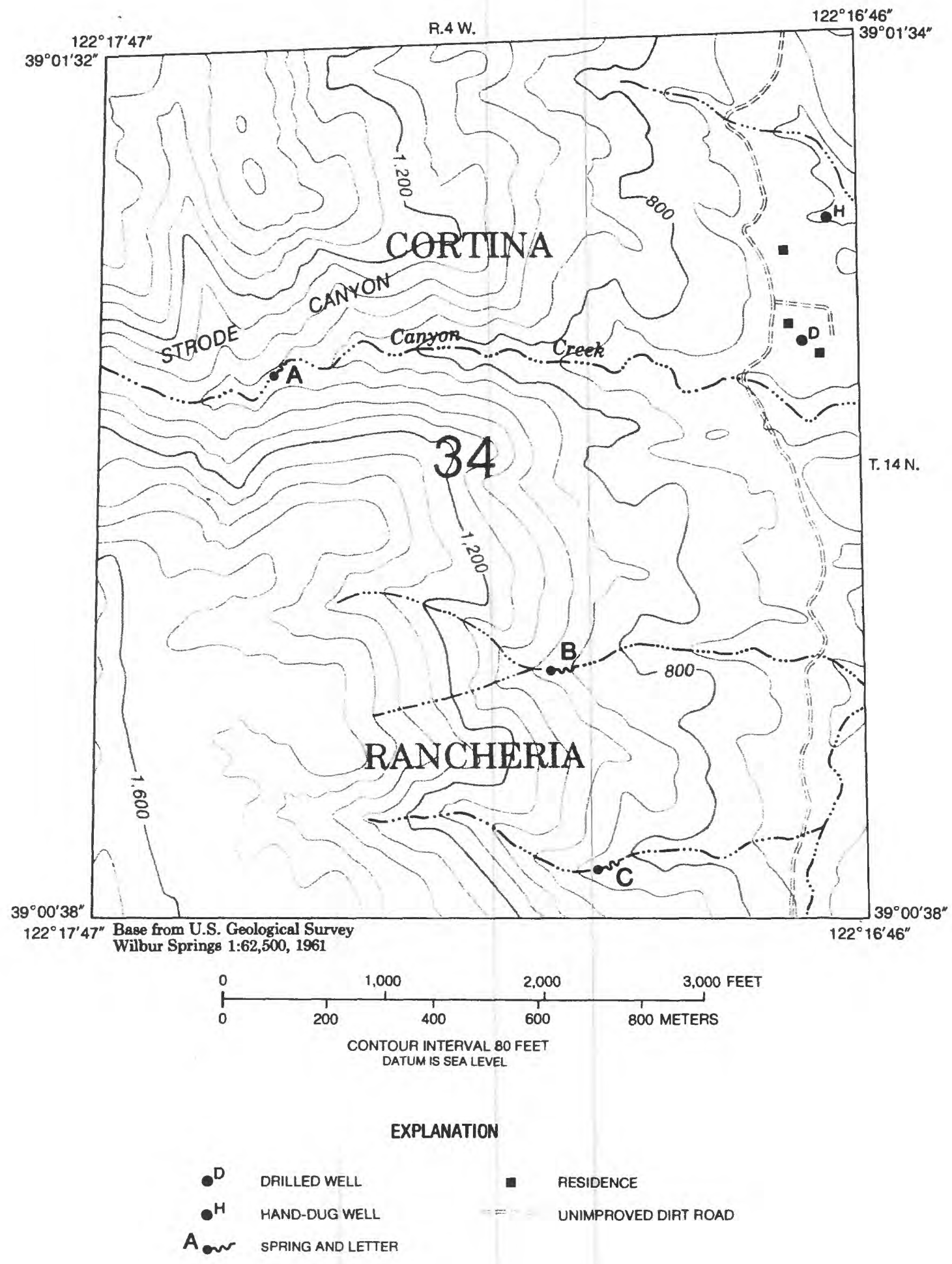

FIGURE 2. Topographic, hydrologic, and eultural features of Cortina Rancheria. 
Drainage patterns in the vicinity of the rancheria are slightly trellislike due to the presence of minor ridges, which parallel the north-south trend of Cortina Ridge. These ridges are caused by outcrops of erosion-resistant geologic formations. Within the rancheria, the principal drainage is through Strode Canyon, which breaches the minor ridges in an east-west direction. The tributary of Cortina Creek flowing through Strode Canyon (fig. 2) is known informally as Canyon Creek (Ott Water Engineers, 1979), and that name is used in this report. Canyon Creek drains an area of $3.1 \mathrm{mi}^{2}$ above the point where it flows out of the rancheria. Canyon Creek usually flows only during the winter and spring.

There are three small springs on the rancheria. Spring $A$ emerges from a deep pool in the streambed of Canyon Creek (fig. 2). Springs B and C emerge in the streambeds of two smaller drainages south of Canyon Creek.

In 1988 , the 23 residents of the rancheria lived in mobile homes near the eastern property boundary (fig. 2). The residents were all members of the Cortina Wintun tribe. Water for domestic purposes was obtained primarily from a well drilled in 1978 near one of the residences (fig. 2). A solar-powered pump delivered water from the well to a 500-gallon storage tank at rates up to $5 \mathrm{gal} / \mathrm{min}$. Electrical power lines from à public utility company were extended to the rancheria in 1987. This service would allow installation of an electric pump capable of delivering the full yield of the well, which has been estimated at $15 \mathrm{gal} / \mathrm{min}$ (Ott Water Engineers, 1979).

A hand-dug well is located close to a stream channel near the northeast corner of the rancheria (fig. 2). The well is 4 feet square and 11 feet deep. Water is obtained by a bucket and used for drinking by two rancheria residents.

\section{Acknowledgments}

The author wishes to express his gratitude to Eric Natti, U.S. Bureau of Indian Affairs, and Mary Norton, chairperson of the Cortina Winton tribe, for their assistance and cooperation in providing information about the hydrology and economic development of Cortina Rancheria.

\section{HYDROGEOLOGY}

The principal geologic formations occurring on the rancheria are the Cortina Formation (Late Cretaceous age) and the Tehama Formation (Pliocene age). The Cortina Formation consists of marine sediments more than 7,000 feet in thickness, which were deposited during the Late Cretaceous Period. The contact between the Cortina Formation and the underlying Unit 2 [Lower and Upper Cretaceous age (Rich, 1971)] is exposed along the western side of Cortina Ridge. Individual members of the Cortina Formation consist of sandstone, siltstone, and shale and were originally mapped as the Venado, Yolo, Sites, and Funks Formations (Kirby, 1943). More recently, as shown in figure 3, they have been grouped simply as Unit 3 of Upper Cretaceous age and mapped as lithologic 


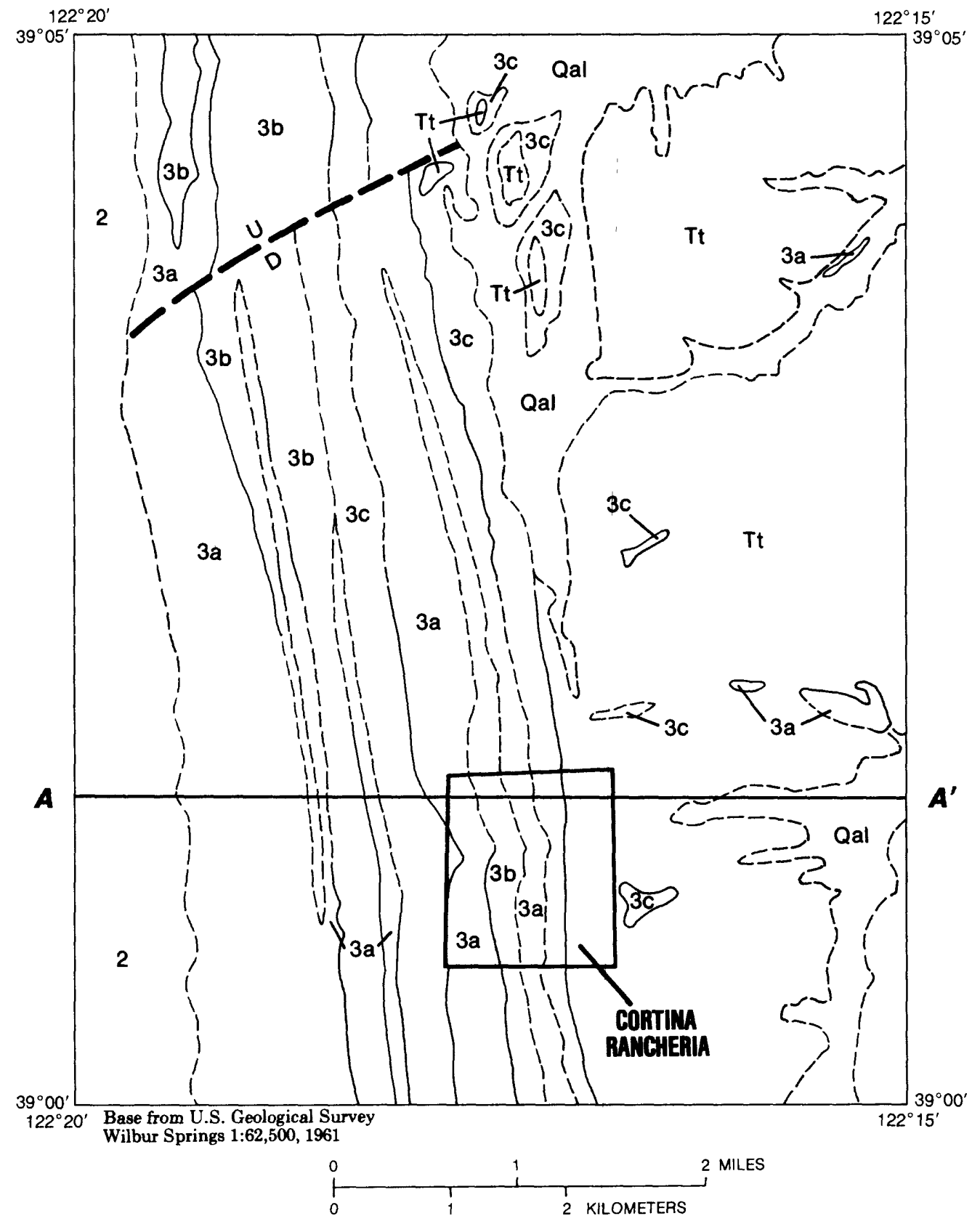

FIGURE 3. Geologic map and section of Cortina Rancheria and vicinity. (Geology modified from Rich, 1971.) 


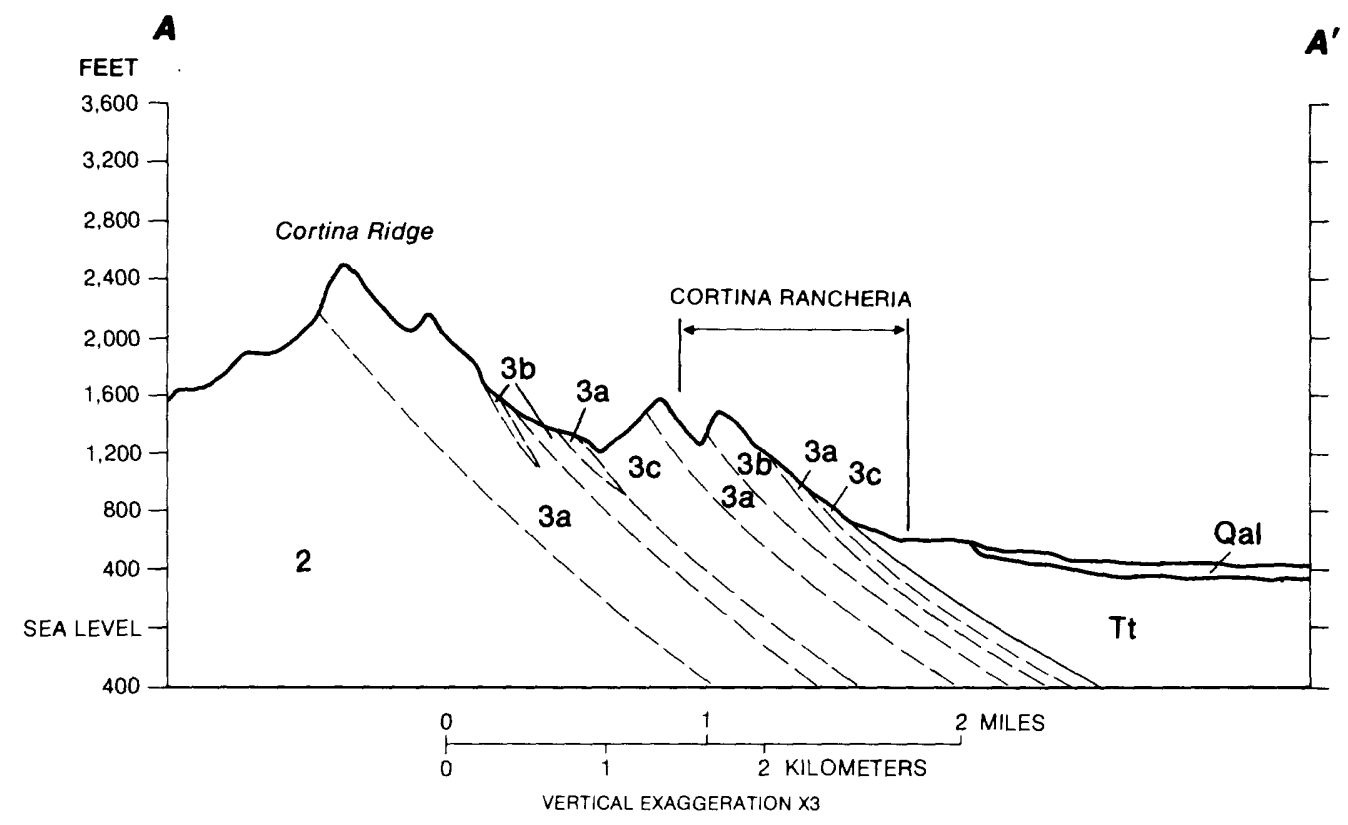

\section{EXPLANATION}

Qal Alluvial deposits (Pleistocene to Holocene). Unconsolidated clay, silt, sand, and gravel

$\mathrm{Tt}$ Tehama Formation (Pliocene). Consolidated claystone containing beds and lenses of Unconformity

$\begin{array}{r}3 c \\ 3 c \\ 3 a \\ \hline\end{array}$

Unit 3, Cortina Formation (Upper Cretaceous)

3a, Sandstone, thin-bedded to massive, fine- to coarse-grained

3b, Sandstone and siltstone, thinly interbedded in about equal amounts

3c. Mudstone and siltstone, thinly bedded to laminated

2 Unit 2 (Lower and Upper Cretaceous)

Mudstone, thinly bedded, containing beds and lenses of silt and sand

Contact, dashed where approximate

Fault, approximately located. U, upthrown side; D, downthrown side

$\mathbf{A}-\mathbf{A}^{\prime} \quad$ Line of section

FIGURE 3. Geologic map and section of Cortina Rancheria and vicinity -- Continued. 
units (Rich, 1971). In this report, Unit 3 and the Cortina Formation are used interchangeably. Tectonic activity and erosion during the Tertiary Period tilted the Cortina Formation steeply to the east and exposed the various members as narrow bands trending in a north-south direction. The lithologic units of the Cortina Formation are exposed sequentially in an eastward direction until they disappear under younger sediments occupying the floor of the Sacramento valley. The sandstone members, more resistant to erosion, form minor north-south ridges along the eastern slopes of Cortina Ridge. A geologic section along an east-west transect is shown in figure 3 . The sediments making up the Cortina Formation contain connate seawater (Olmsted and Davis, 1961), and so they have not been developed as a source of water.

The Cortina Formation is unconformably overlain by the Tehama Formation, which was deposited in a freshwater environment during the Pliocene Epoch. The contact between the Cortina and Tehama Formations crosses Cortina Rancheria in a north-south direction about 2,000 feet west of the eastern property boundary (fig. 3). The Tehama Formation thickens eastward to more than 2,000 feet near the middle of the Sacramento Valley (Olmsted and Davis, 1961).

The maximum thickness of the Tehama Formation near the eastern boundary of Cortina Rancheria is disputed. The driller's log from the well drilled in 1978 indicated that the subsurface deposits resembled Tehama Formation throughout the 400-foot depth of the borehole (Ott Water Engineers, 1979). A later study found that outcrop exposures in a nearby creekbed indicated a thickness of only 75 feet (Gasch and Associates, 1982).

The Tehama Formation consists of poorly sorted fluvial sediments and occasional volcanic tuffs. The sediments derived from the Coast Ranges to the west and consist mainly of sandy or silty clays and lenses of sand or gravel. The sediments are compacted but not cemented and have been subjected to slight tectonic deformation (Olmsted and Davis, 1961; Rich, 1971; California Department of Water Resources, 1978). The Tehama Formation generally contains freshwater.

The Tehama Formation is generally much less permeable than younger alluvial deposits (Quaternary age) that overlie it along stream channels near Cortina Rancheria and throughout much of the central part of the Sacramento valley. Consequently, most wells in the western part of the valley are completed in the alluvial deposits. Water wells have been drilled into the Tehama Formation where younger alluvial deposits are absent, such as near the town of Dunnigan, 20 miles to the southeast (fig. 1), or where a sufficient thickness of coarse-grained lenses occur, such as in southwestern Tehama County 65 miles to the north. Near Cortina Rancheria and for a distance of about 40 miles to the north, the Tehama Formation is dominantly fine grained. The few wells in this area are shallow, low-yield wells used for domestic or stock-watering purposes. Storage coefficients of the Tehama Formation also are lower than those of the overlying alluvial deposits, as indicated by larger seasonal fluctuations in ground-water levels (U.S. Bureau of Reclamation, 1958; Olmsted and Davis, 1961; Bertoldi, 1976; California Department of Water Resources, 1978). 
Data from individual wells in the vicinity of Cortina Rancheria are generally consistent with the regional pattern of low yields and low aquifer permeability. A well drilled to a depth of 42 feet near the western edge of the Tehama Formation at a location 5 miles north of the rancheria was dry. Another well drilled a half-mile farther south yielded $6 \mathrm{gal} / \mathrm{min}$ in a bailing test, even though its depth is only 34 feet. A well 3 miles north of the rancheria penetrated broken lava near the base of the Tehama Formation, between 50 and 80 feet below land surface. The well yielded $100 \mathrm{gal} / \mathrm{min}$ during an aquifer test (Earl Hansen, California Department of Water Resources, written commun., 1986).

The drilled well on the rancheria probably penetrates 75 feet of Tehama Formation and 325 feet of Cortina Formation (Gasch and Associates, 1982). Total screen length is 338 feet. When the well was drilled in August 1978, the standing water level was 62 feet below land surface. The water level declined 23 feet when the well was pumped at $15 \mathrm{gal} / \mathrm{min}$, indicating a specific capacity of 0.65 (gal/min)/ft (Ott Water Engineers. 1979). This specific capacity probably corresponds to a transmissivity of between 35 and $130 \mathrm{ft} / \mathrm{d}$, if one assumes a well radius between 0.5 and 1.5 feet, a storage coefficient between 0.1 and 0.001 , and an aquifer-test duration between 2 and 12 hours. This transmissivity, however, is for a screened interval that includes both the Cortina and Tehama Formations. The transmissivity of the Tehama Formation by itself is smaller by an unknown amount, and if the drilled well were sealed off to a depth of 75 feet in order to tap only the Tehama Formation, the yield would be smaller.

\section{RAINFALL AND RUNOFF}

Mean annual rainfall at Cortina Rancheria is about 22 inches (Rantz, 1969). Rainfall data for 13 nearby stations, all of which have more than 20 years of record, ranged from 14.1 to 31.6 inches (California Department of Water Resources, 1981). This variability appeared to be related to topographic effects, which could be particularly large in the vicinity of Cortina Ridge. Mean annual rainfall for the entire Canyon Creek drainage area, which has a higher average altitude than the rancheria, is probably about 23 inches.

Runoff from the drainage area of Canyon Creek was estimated from rainfallrunoff relations for seven unregulated, gaged streams on the west side of Sacramento Valley (table 1). Locations of these streams are shown in figure 1. Figure 4 shows the relation between mean annual runoff per unit area and mean annual rainfall. No adjustments were made to account for differences in slope, altitude, vegetative cover, potential evapotranspiration, or land use. A regression analysis of rainfall and runoff in the north-coast region of California indicated that such factors have minor effects on runoff (Crippen and Beall, 1970). The relation in figure 4 illustrates a threshold effect and indicates that in general little or no runoff occurs in drainage areas receiving less than about 16 inches of rainfall per year. Above the threshold, runoff per unit area increases in an approximately linear relation to rainfall. 
TABLE 1.--Characteristics of selected streams along the west side of the Sacramento Valley

[Data from U.S. Geological Survey (1942-70, 1971-74, 1976-82) and California Department of Water Resources (1981). Mean annual rainfall values are from Rantz (1969) for the period 1911-60. $\mathrm{mi}^{2}$, square miles; $\mathrm{ft}^{3} / \mathrm{s}$, cubic feet per second]

\begin{tabular}{|c|c|c|c|c|c|}
\hline $\begin{array}{c}\text { Gaging station name and No. } \\
\text { (fig. 1) }\end{array}$ & $\begin{array}{l}\text { Period } \\
\text { of } \\
\text { stream- } \\
\text { flow } \\
\text { record }\end{array}$ & $\begin{array}{c}\text { Drainage } \\
\text { area } \\
\left(\mathrm{mi}^{2}\right)\end{array}$ & $\begin{array}{c}\text { Estimated } \\
\text { mean } \\
\text { annual } \\
\text { rainfall } \\
\text { (inches) }\end{array}$ & $\begin{array}{c}\text { Mean } \\
\text { annual } \\
\text { flow } \\
\left(f t^{3} / s\right)\end{array}$ & $\begin{array}{c}\text { 100-year } \\
1 \text {-day } \\
\text { peak flow } \\
\left(\mathrm{ft}^{3} / \mathrm{s}\right)\end{array}$ \\
\hline $\begin{array}{l}\text { Middle Fork Cottonwood Creek } \\
\text { near Ono (11374400) }\end{array}$ & $1958-72$ & 244 & 40 & 254 & 20,400 \\
\hline $\begin{array}{l}\text { Red Bank Creek near } \\
\quad \text { Red Bluff }(11378800)\end{array}$ & $1961-77$ & 93.5 & 24 & 44.3 & 5,010 \\
\hline $\begin{array}{l}\text { Elder Creek at Gerber } \\
\quad(11380500)\end{array}$ & $1952-68$ & 136 & 30 & 96.2 & 10,400 \\
\hline $\begin{array}{l}\text { Thomes Creek at Paskenta } \\
(11382000)\end{array}$ & $1942-76$ & 194 & 45 & 304 & 22,500 \\
\hline $\begin{array}{l}\text { Grindstone Creek near } \\
\text { Elk Creek (11386500) }\end{array}$ & $1965-72$ & 156 & 47 & 193 & 16,800 \\
\hline $\begin{array}{l}\text { Stone Corral Creek } \\
\text { near Sites }(11390672)\end{array}$ & $1959-77$ & 38.2 & 21 & 6.1 & 2,540 \\
\hline $\begin{array}{l}\text { Bear Creek near Rumsey } \\
\quad(11451720)\end{array}$ & $1959-77$ & 100 & 27 & 44.3 & 5,140 \\
\hline Canyon Creekl & -- & 3.1 & 23 & 1.0 & 870 \\
\hline
\end{tabular}

lNot a gaged stream. Location of stream shown in figure 2. Runoff values were estimated from rainfall-runoff relations of the seven other streams included.

The regression equation for the rainfall-runoff relation (fig. 4) is

$$
R=0.621 P-9.82
$$

where

$R$ is annual runoff per unit area, in inches; and

$P$ is annual rainfall, in inches.

The coeffient of determination, which is a measure of the scatter of the data, is 0.92 . If the data points all fell perfectly on a straight line, the coefficient of determination would equal 1.0. The equation indicates that mean annual runoff per unit area in the Canyon Creek basin is about 4.5 inches. 


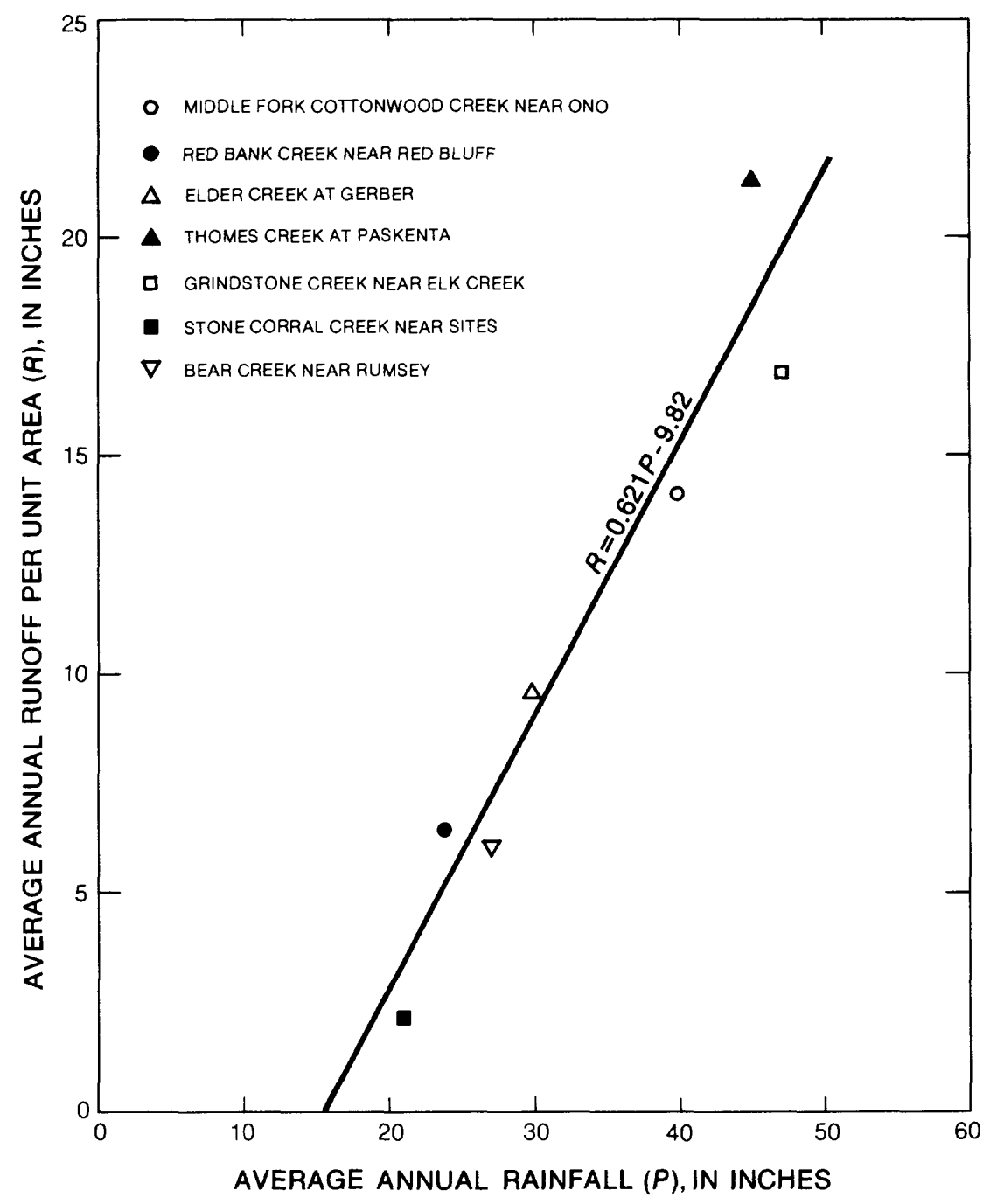

FIGURE 4. Relation between average annual runoff per unit area and average annual rainfall for selected drainage areas along the west side of the Sacramento Valley. Data from U.S. Geological Survey (1942-70; 1971-74; 1976-82); California Department of Water Resources (1981); Fogelman and others (1983); Fogelman and others (1984); and Mullen and others (1985 and 1987).

Mean annual flow is therefore $1.0 \mathrm{ft}^{3} / \mathrm{s}$ (table 1 ), and flow volume is 720 acre$\mathrm{ft} / \mathrm{yr}$. Because of the small number of data points used for regression, the 95-percent confidence interval for mean annual runoff is large, ranging from 240 to 1,200 acre-ft/yr.

Assuming an average per capita water consumption rate of $75 \mathrm{gal} / \mathrm{d}$ for indoor domestic use, a population of 100 residents would consume less than 2 percent of the average annual runoff in Canyon creek. In order to use this water, however, means would have to be provided for storage. 
Flow in streams on the west side of the Sacramento Valley is highly seasonal, and most smaller streams dry up in summer. Dimensionless flow-duration curves for seven streams are shown in figure 5. The curves, developed from published streamflow data (U.S. Geological Survey, 1942-70, 1971-74, and 1976-82; Fogelman and others, 1983; Fogelman and others, 1984; and Mullen and others, 1985 and 1987), show the percentage of time that flow in each stream is greater than specified amounts, where the amounts are expressed as multiples or fractions of long-term average flow. Of the seven streams shown, the more ephemeral ones are those with steeper lines that intersect the bottom of the graph farther to the left. Characteristics of each stream and the estimated magnitudes of the 100-year, 1-day peak flow are shown in table 1 . The data indicate that smaller streams tend to be more ephemeral.

of the streams included in figure 5 and table 1, Stone corral Creek is probably most similar to Canyon Creek. Stone Corral Creek's drainage area of $38.2 \mathrm{mi}^{2}$ is the smallest of these streams, but it is still 12 times greater than that of Canyon Creek. Nevertheless, data for Stone Corral Creek were emphasized in developing estimates of minimum and peak flows in Canyon Creek.

The 100-year, 1-day peak flow is the maximum average flow for a 24-hour period likely to occur once in 100 years. It may be useful in designing diversion or recharge projects on Canyon Creek, even though the instantaneous peak flow may be considerably larger. For example, discharge records for stone Corral Creek indicate that instantaneous peak flow on the day of 1 -day peak flow is typically three to seven times larger than the 1-day peak flow.

The data in table 1 indicate that the 100-year, 1-day peak flow is related to drainage area and mean annual precipitation. A multiple regression using these two predictors, weighted to emphasize Stone Corral Creek, yields the following equation:

$$
Q=52.1 A+407 P-8,652
$$

where

$Q$ is 100-year, 1-day peak flow, in cubic feet per second;

$A$ is drainage area, in square miles; and

$P$ is mean annual rainfall, in inches.

The coefficient of determination is 0.96. The equation indicates that the 100-year, 1-day peak flow for Canyon Creek is about $870 \mathrm{ft}^{3} / \mathrm{s}$. This calculated value may contain significant errors because (1) the regression data are scattered and (2) the drainage area of Canyon Creek ( $3.1 \mathrm{mi}^{2}$ ) lies outside the range of values used for regression ( 38 to $244 \mathrm{mi}^{2}$ ).

From the standpoint of water supply, periods of low flow are of more concern than peak flows. Stone Corral Creek typically is dry from May through November and occasionally remains dry throughout the winter. It was dry for two consecutive winters during the 1976-77 drought. Fitting stone Corral Creek flow data for 1959-77 to a log Pearson type III probability distribution indicates that the recurrence interval of a winter without flow is 12 to 14 years. The recurrence interval is probably shorter for Canyon Creek because its drainage area is much smaller. Because years of no flow are not rare, 


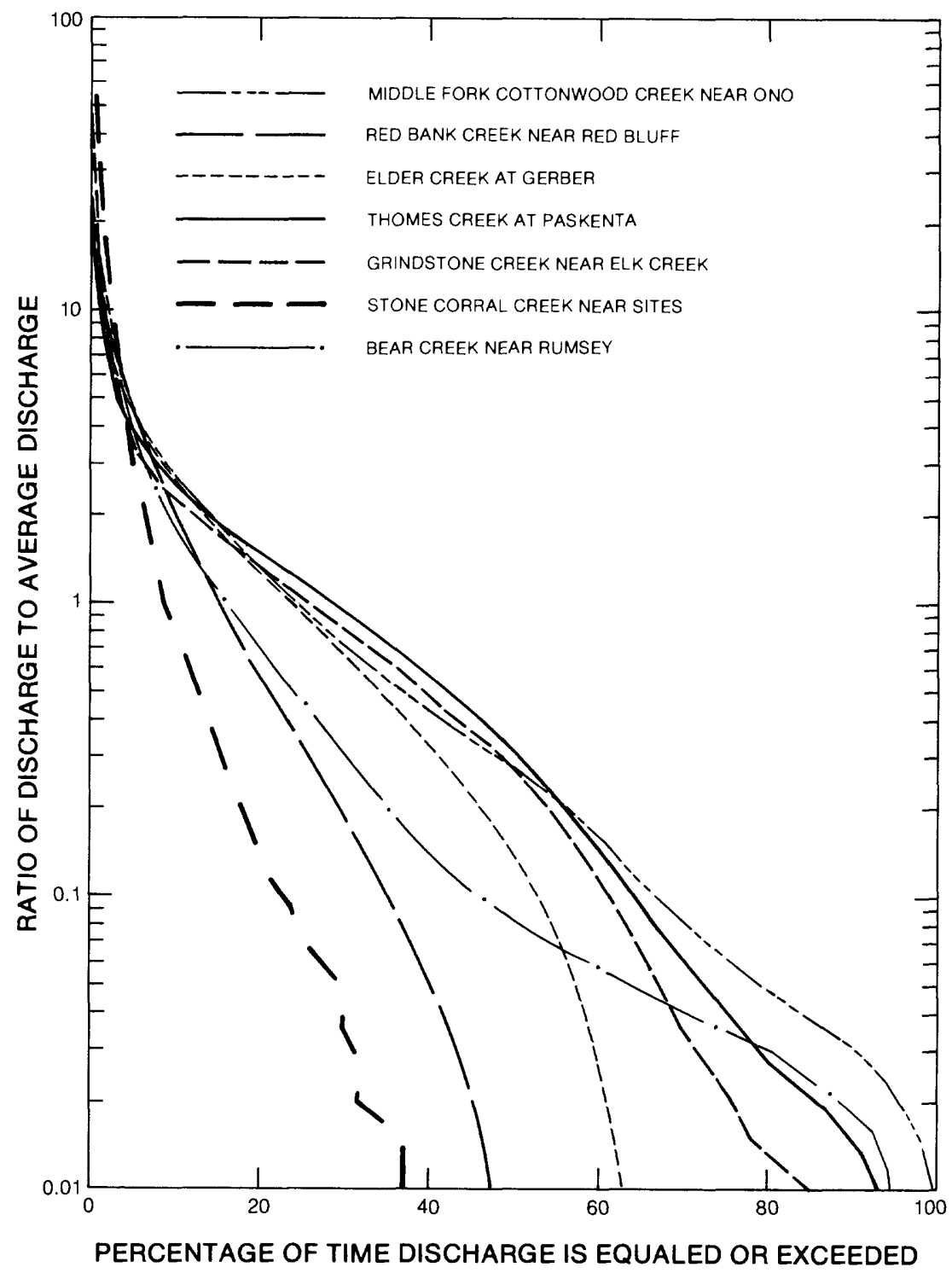

FIGURE 5. Dimensionless flow-duration curves for selected stream-gaging stations along the west side of the Sacramento Valley. Data from U.S. Geological Survey (1942-70; 1971-74; 1976-82); Fogelman and others (1983); Fogelman and others (1984); and Mullen and others (1985 and 1987).

diversions from Canyon Creek would not be reliable in the long run unless facilities were provided for storing two to three times the average annual volume of diversion.

Flow from springs might offer a small but dependable supply of water. In September 1986, springs B and $C$ were both flowing at a rate of about 0.2 $\mathrm{gal} / \mathrm{min}$. Discharge at a natural bedrock weir immediately downstream of spring A was $5 \mathrm{gal} / \mathrm{min}$. The winter of 1986 was wetter than average, so that it is not known whether the springs cease to flow following dry winters. 


\section{WATER QUALITY}

\section{Surface Water}

Water-quality data for nine streams along the west side of the Sacramento Valley are given in table 2. Concentrations of dissolved solids ranged from 140 to $1,300 \mathrm{mg} / \mathrm{L}$ (milligrams per liter) and averaged $687 \mathrm{mg} / \mathrm{L}$. Chloride concentrations ranged from 2 to $360 \mathrm{mg} / \mathrm{L}$ and averaged $183 \mathrm{mg} / \mathrm{L}$. This pattern of high dissolved-ion concentrations results from the occurrence of exposed marine sediments in the drainage areas of most streams along the west side of the Sacramento valley.

Five years of monthly water-quality data from Thomes Creek indicate that water quality is generally related to discharge. Specific conductance (SC) and chloride concentration (figs. 6 and 7 ) tend to be lower during high flow, especially flow greater than $500 \mathrm{ft}^{3} / \mathrm{s}$, because of dilution by rainfall runoff.

Flows greater than $500 \mathrm{ft}^{3} / \mathrm{s}$ in Thomes Creek occur only 18 percent of the time but account for about 70 percent of the annual volume of discharge. These flows tend to occur in winter and spring (fig. 8). Semiannual water-quality data from other streams along the west side of the Sacramento valley reveal a similar pattern of high SC and dissolved-ion concentrations in autumn and low

TABLE 2.--Water quality of selected streams along the west side of the Sacramento Valley

[Data are from U.S. Geological Survey $(1942-70,1976-82)$. $\mu \mathrm{S} / \mathrm{cm}$ at $25^{\circ} \mathrm{C}$, microsiemens per centimeter at 25 degrees Celsius; mg/L, milligrams per liter. Location of sites in fig. 1]

\begin{tabular}{|c|c|c|c|c|c|}
\hline $\begin{array}{l}\text { Site } \\
\text { No. }\end{array}$ & Location & $\begin{array}{l}\text { Sampling } \\
\text { date }\end{array}$ & $\begin{array}{c}\text { Specific } \\
\text { conductance } \\
(\mu \mathrm{s} / \mathrm{cm} \\
\left.\text { at } 25^{\circ} \mathrm{C}\right)\end{array}$ & $\begin{array}{l}\text { Chloride, } \\
\text { dissolved, } \\
\text { as C1 } \\
(\mathrm{mg} / \mathrm{L})\end{array}$ & $\begin{array}{l}\text { Solids, } \\
\text { residue } \\
\text { at } 180{ }^{\circ} \mathrm{C}, \\
\text { dissolved } \\
(\mathrm{mg} / \mathrm{L})\end{array}$ \\
\hline 1 & Thomes Creek & $5-06-65$ & 234 & 2 & 140 \\
\hline 2 & Stony Creek & $3-21-79$ & 385 & 29 & 226 \\
\hline 3 & Stone Corral Creek & $4-17-79$ & 1,800 & 340 & 1,000 \\
\hline 4 & Lurline Creek & $4-17-79$ & 668 & 50 & 370 \\
\hline 5 & Freshwater Creek & $4-17-79$ & 1,850 & 330 & 1,000 \\
\hline 6 & Salt Creek (upper) & $4-17-79$ & 1,780 & 270 & 1,000 \\
\hline 7 & Salt Creek (lower) & $4-02-75$ & 2,120 & 360 & 1,000 \\
\hline 8 & Cortina Creek & $4-18-79$ & 1,110 & 120 & 650 \\
\hline 9 & Sand Creek & $4-17-79$ & 920 & 150 & 500 \\
\hline
\end{tabular}




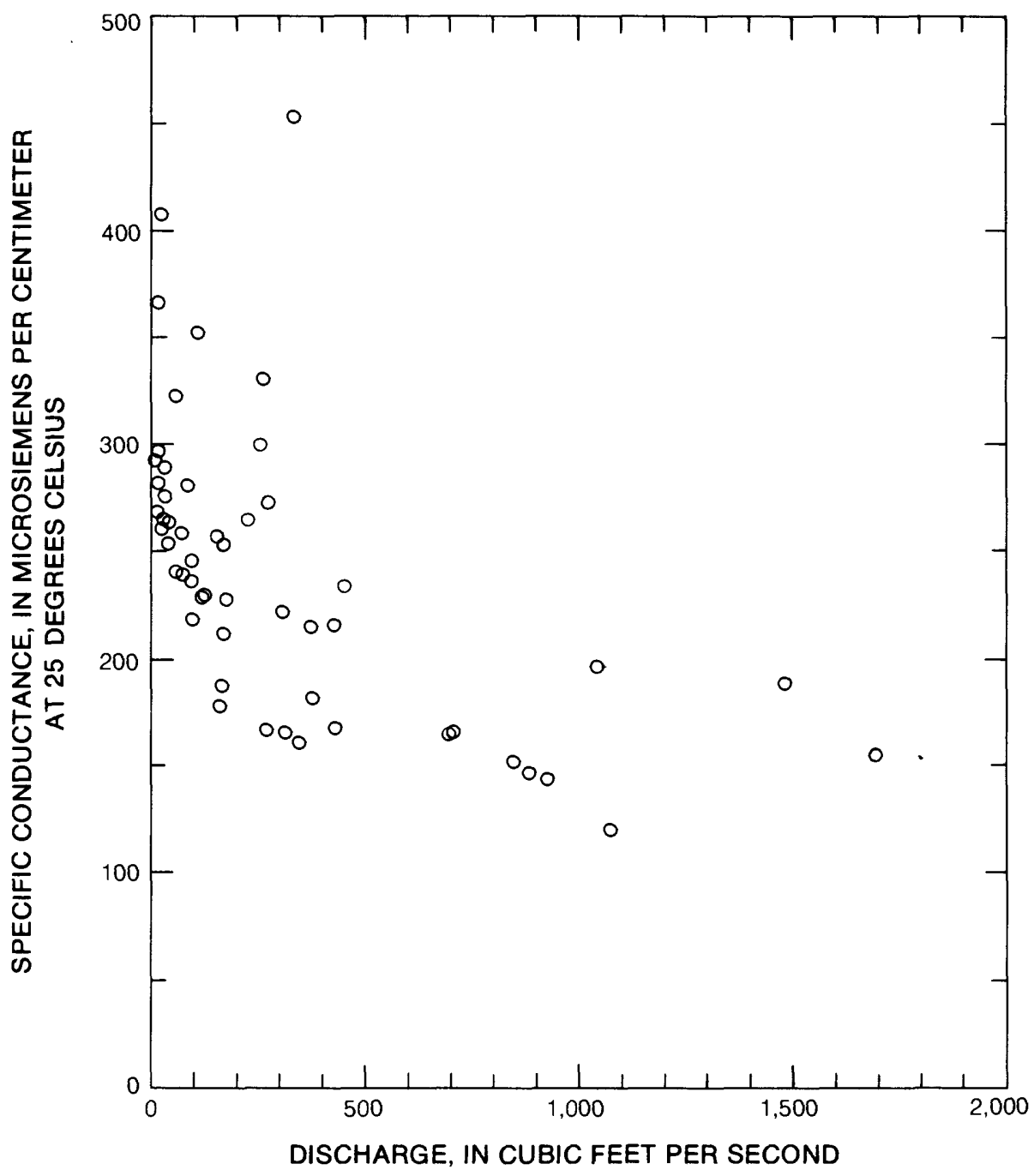

FIGURE 6. Relation between specific conductance and discharge in Thomes Creek.

Data are from U.S. Geological Survey (1942-70).

SC and dissolved-ion concentrations in spring (California Department of Water Resources, 1978; Fogelman and Evenson, 1984). In some streams, the high salinity associated with low flow results from concentrated brines emerging from saline springs scattered throughout the eastern part of the Coast Ranges.

If water were diverted from Canyon Creek to maximize improvement in the quality of the water supply for Cortina Rancheria, diverting peak flows in winter would be more advantageous than diverting a smaller amount of flow year-round. 


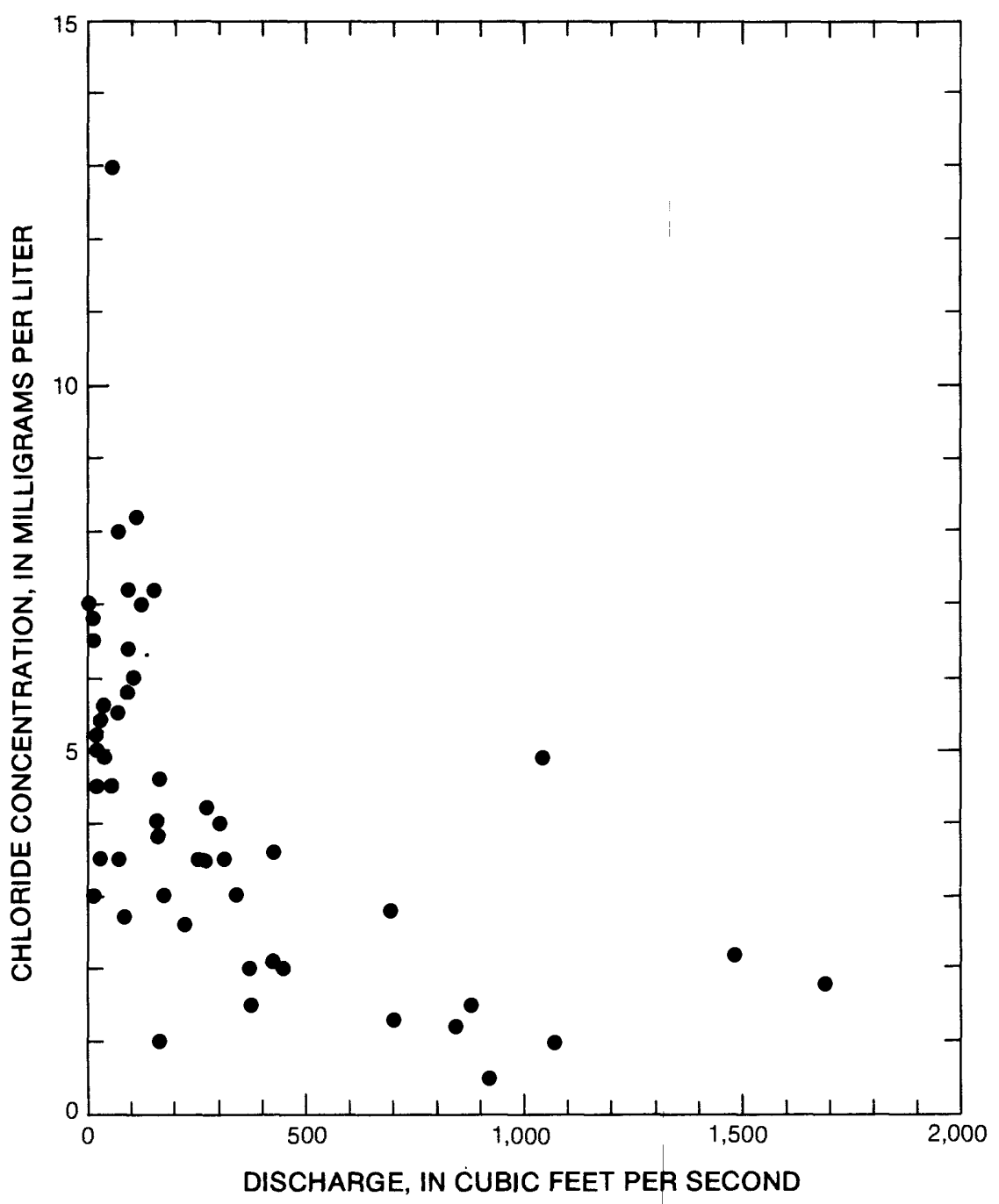

FIGURE 7. Relation between chloride concentration and discharge in Thomes Creek. Data are from U.S. Geological Survey (1942-70).

The quality of surface water on Cortina Rancheria has not been measured. Although samples of water from two springs have been analyzed, the samples were not collected during periods of surface runoff and are more indicative of ground- than surface-water quality. Because of similarities in geology, climate, and land use, the quality of surface water on the rancheria is probably within the range defined by other streams along the west side of the Sacramento Valley. 
SกISา

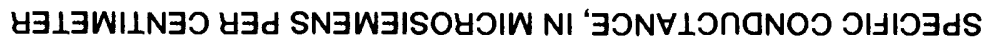

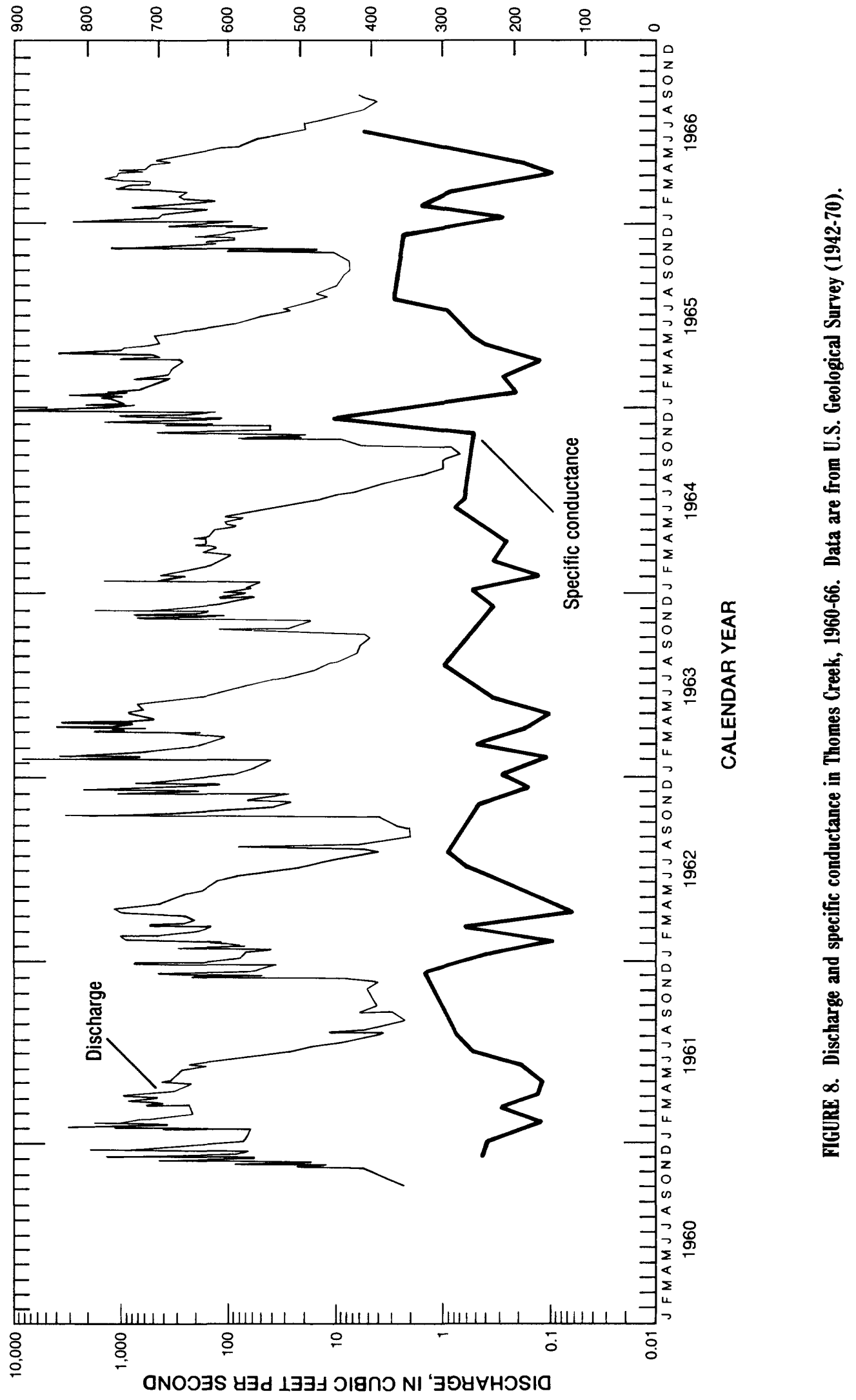




\section{Ground Water}

Concentrations of dissolved ions in shallow ground water in the western half of Sacramento Valley are considerably higher than in the eastern half (California Department of Water Resources, 1978). Many of the ions, especially sodium, chloride, fluoride, and boron, probably originate from connate seawater deposited with the marine sediments that make up the Coast Ranges and underlie the Tehama Formation. In the southwestern part of the Sacramento Valley, especially between Williams and Arbuckle (fig. 1), the concentration of dissolved solids commonly exceeds $500 \mathrm{mg} / \mathrm{L}$. Concentrations of sodium and boron are high enough to restrict agricultural use of the water (California Department of Water Resources, 1978; Hull, 1984).

In a few areas, upward movement of ground water carries dissolved ions from the marine sediments into the fresh ground water of the overlying sediments. More commonly, dissolved ions in surface streams enter fresh ground water during natural recharge processes. Some of the salinity in the surface streams is derived from saline springs. The rest is picked up from marine sediments over a wide area by rainwater, which infiltrates and reemerges as base flow in the streams (Hull, 1984). In a few areas along the western edge of the Sacramento Valley, marine sediments have been flushed completely of connate seawater and now contain fresh ground water (Olmsted and Davis, 1961).

A survey of wells in the Tehama-Colusa Canal service area (Bertoldi, 1976), which includes a large area between Red Bluff and Dunnigan (fig. 1), found that 75 percent of the wells had water classified as very hard (hardness greater than the equivalent of $180 \mathrm{mg} / \mathrm{L}$ calcium carbonate). The highest concentrations of sulfate ion (51 to $150 \mathrm{mg} / \mathrm{L}$ ) in the service area were found in wells between Spring and Freshwater Creeks, 5 to 10 miles north of Cortina Rancheria (fig. 1). The highest concentrations of dissolved solids (greater than $500 \mathrm{mg} / \mathrm{L}$ ) were found along the two Salt Creeks (fig. 1), 8 miles north and 10 miles south of the rancheria, respectively.

These regional patterns indicate that ground-water quality throughout the western part of the Sacramento Valley is generally poor, although local variability in ground-water quality can be considerable. For example, data for three wells less than 3 miles apart near Freshwater Creek showed concentrations of dissolved solids ranging from 440 to $832 \mathrm{mg} / \mathrm{L}$ and chloride concentrations ranging from 79 to $220 \mathrm{mg} / \mathrm{L}$ (U.S. Geological Survey, 1971-74).

Seasonal variations in ground-water quality are similar to those in surface-water quality. For example, at one well 6 miles east of Cortina Rancheria, four water-quality samples collected in late summer in 3 different years had an average specific conductance (SC) of $894 \mu \mathrm{S} / \mathrm{cm}$ at $25{ }^{\circ} \mathrm{C}$ (microsiemens per centimeter at 25 degrees Celsius). Two samples collected in early summer averaged only $679 \mathrm{\mu S} / \mathrm{cm}$ (U.S. Geological Survey, 1942-70, 1971-74, 1976-82; Fogelman and others, 1983; Fogelman and others, 1984; and Mullen and others, 1985 and 1987). 
Water-quality samples from the drilled well, the hand-dug well, and springs $A$ and $C$ were collected for this study on September 19, 1986. Results of the analyses are summarized in table 3. Data for the same sites collected during a previous investigation (Ott Water Engineers, 1979) are also included in table 3, although the accuracy of these data is not known. For comparison, State of California (1985) drinking-water standards are also given.

The data in table 3 reveal considerable variation in water quality over space and time, even within Cortina Rancheria. Some properties and constituents had fairly uniform values in all samples, including $\mathrm{pH}$ and concentrations of total organic carbon, nitrogen, fluoride, silica, arsenic, cadmium, chromium, silver, selenium, and mercury. Other properties and constituents varied considerably from place to place. For example, SC measurements were all less than $1,800 \mu \mathrm{S} / \mathrm{cm}$ at spring $C$ and all greater than $3,700 \mu \mathrm{S} / \mathrm{cm}$ at spring $A$. Similarly, hardness (as $\mathrm{CaCO}_{3}$ ) ranged from 63 to $1,200 \mathrm{mg} / \mathrm{L}$, chloride concentrations ranged from 14 to $1,245 \mathrm{mg} / \mathrm{L}$, calcium concentrations ranged from 12 to $270 \mathrm{mg} / \mathrm{L}$, and the sodium adsorption ratio ranged from 1 to 20 . Some properties and constituents varied noticeably with time. For example, the data from ott Water Engineers (1979) indicated that chloride concentration at the drilled well was $1,245 \mathrm{mg} / \mathrm{L}$ on september 5,1978 , and decreased to $251 \mathrm{mg} / \mathrm{L}$ on October 27. During the same period, sulfate concentration increased from 7 to $140 \mathrm{mg} / \mathrm{L}$. Two SC measurements in autumn 1978 were between 1,300 and $1,400 \mu \mathrm{S} / \mathrm{cm}$, but in autumn 1986 the SC measurement was 2,150 $\mu \mathrm{S} / \mathrm{cm}$.

\section{Water Quality and Supply}

The data in table 3 indicate that the quality of ground water on Cortina Rancheria is generally poor for drinking or irrigation uses. Concentrations of barium and lead in water from the drilled well each exceeded the primary drinking-water standards on one occasion. In both cases, however, the measurements were anomalously high compared to concentrations measured on other occasions. If the two data points are not in error, they may represent transient variations which could be offset for practical purposes by blending water from several sources or by using a storage reservoir to offset transient water-quality fluctuations.

Secondary drinking-water standards (State of California, 1985) regulate constituents that may be objectionable from an esthetic standpoint but that pose little or no health risk. Most of the samples failed to meet secondary standards. The concentration of dissolved solids ranged as high as $3,340 \mathrm{mg} / \mathrm{L}$ and exceeded the maximum permissible level of $1,000 \mathrm{mg} / \mathrm{L}$ at all sites except spring $C$, where a concentration of $960 \mathrm{mg} / \mathrm{L}$ was measured. Specific conductance (SC), which generally correlates closely with dissolved solids, exceeded the standard of $1,600 \mu \mathrm{S} / \mathrm{cm}$ at least once at all sites, including spring $\mathrm{C}$. 
TABLE 3.--Water-quality data for Cortina Rancheria and drinking-water standards for California

[Drinking-water standards are from State of California (1985). Data for 1978 are from Ott Water Engineers (1979). Values are in milligrams per liter unless otherwise indicated. Field bicarbonate determined by incremental titration method. MBAS, methylene blue active isubstances. $\mu \mathrm{g} / \mathrm{L}$, micrograms per 11 ter; $\mu \mathrm{S} / \mathrm{cm}$ at $25^{\circ} \mathrm{C}$, microsiemens per centimeter at 25 degrees Celsius; <, actual value is less than value shown; ${ }^{\circ} \mathrm{C}$, degrees Celsius; --, no data]

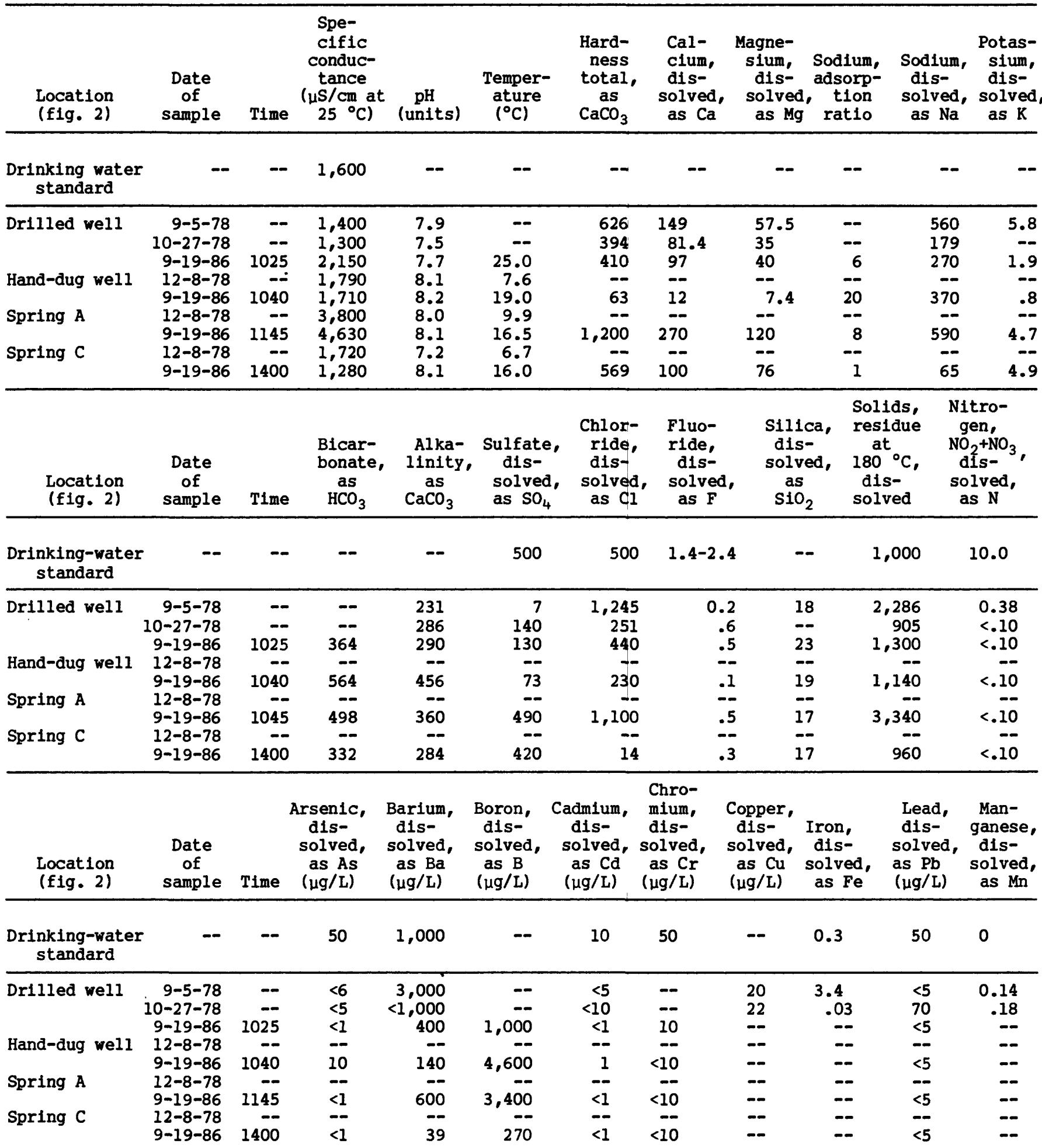


TABLE 3.--Water-quality data for Cortina Rancheria and drinking water standards for California--Continued

\begin{tabular}{|c|c|c|c|c|c|c|}
\hline $\begin{array}{l}\text { Location } \\
\text { (fig. 2) }\end{array}$ & $\begin{array}{c}\text { Date } \\
\text { of } \\
\text { sample }\end{array}$ & $\begin{array}{c}\text { Mercury, } \\
\text { dis- } \\
\text { solved, } \\
\text { as Hg } \\
(\mu g / L)\end{array}$ & $\begin{array}{l}\text { Sele- } \\
\text { nium, } \\
\text { dis- } \\
\text { solved, } \\
\text { as Se } \\
(\mu \mathrm{g} / \mathrm{L})\end{array}$ & $\begin{array}{c}\text { Silver, } \\
\text { dis- } \\
\text { solved, } \\
\text { as Ag } \\
(\mu \mathrm{g} / \mathrm{L})\end{array}$ & $\begin{array}{c}\text { Carbon, } \\
\text { organic, } \\
\text { total } \\
\text { as C } \\
(\mu g / L)\end{array}$ & $\begin{array}{c}\text { Foaming } \\
\text { agents } \\
\text { (MBAS) }\end{array}$ \\
\hline $\begin{array}{l}\text { Drinking water } \\
\text { standard }\end{array}$ & -- & 2.0 & 10 & 50 & - & 0.5 \\
\hline Drilled well & $\begin{array}{r}9-5-78 \\
10-27-78 \\
9-19-86\end{array}$ & $\begin{array}{l}<1 \\
<1 \\
<1\end{array}$ & $\begin{array}{l}<2 \\
<10 \\
<1\end{array}$ & $\begin{array}{l}<10 \\
<1 \\
<1\end{array}$ & $\overline{--}$ & $<1.0$ \\
\hline \multirow{2}{*}{ Hand-dug well } & $12-8-78$ & $\because$ & -- & $=-$ & $\begin{array}{l}4.2 \\
--\end{array}$ & - \\
\hline & $9-19-86$ & $<.1$ & $<1$ & $<1$ & 3.2 & -- \\
\hline Spring A & $\begin{array}{l}12-8-78 \\
9-19-86\end{array}$ & $-\overline{1}$ & $=-$ & -- & $=-\overline{7}$ & -- \\
\hline \multirow{2}{*}{ Spring C } & $\begin{array}{l}9-19-86 \\
12-8-78\end{array}$ & $=1$ & $<1$ & $\begin{array}{l}<1 \\
--\end{array}$ & $\begin{array}{l}3.7 \\
--\end{array}$ & $=$ \\
\hline & $9-19-86$ & .2 & $<1$ & $<1$ & 3.8 & -- \\
\hline
\end{tabular}

Concentrations of manganese, iron, and foaming agents (methylene blue active substances, MBAS) occasionally exceeded secondary drinking-water standards in water from the drilled well. Chloride, which gives water a salty taste, was near or above recommended concentrations at the drilled well and spring $A$. In contrast, spring $C$ had a remarkably low chloride value of $14 \mathrm{mg} / \mathrm{L}$.

Use of ground water for irrigation might also be limited by water-quality considerations. The water-quality characteristics of principal concern from an agricultural standpoint are SC, sodium-adsorption ratio, and concentrations of chloride and boron (Bohn and others, 1979). Different crops have a wide range of tolerances to these water-quality characteristics. The high SC of water from spring $A(3,800$ to $4,630 \mu \mathrm{S} / \mathrm{cm})$ might cause slightly reduced yields in a wide variety of forage, field, and vegetable crops. Specific conductance of water from the other sites was generally below $2,000 \mu \mathrm{S} / \mathrm{cm}$ and would probably pose few problems except to a few sensitive vegetable crops, such as green beans, carrots, onions, bell peppers, and lettuce (Bohn and others, 1979).

The high sodium-adsorption ratio of water from the hand-dug well would limit its use for irrigating deciduous fruit, citrus, nut, and avocado trees. Water from the other locations would not present a sodium hazard. Chloride concentrations in water from the drilled well, spring $A$, and possibly the hand-dug well could pose a problem for many crops. In contrast, water from spring $C$ had a low chloride concentration.

Crops are considered tolerant of boron if they are unaffected by concentrations ranging from 2,000 to $4,000 \mu \mathrm{g} / \mathrm{L}$ (Bohn and others, 1979). Concentrations at the hand-dug well and spring $A$ were 4,600 and $3,400 \mu g / L$, respectively. Water from the drilled well could be used on crops semitolerant to boron ( 1,000 to $2,000 \mu \mathrm{g} / \mathrm{L}$ boron). Sensitive crops, which include most fruit trees, would grow best with water from spring $C$, which had a boron concentration of only about $300 \mu \mathrm{g} / \mathrm{L}$. 
The variability of ground-water quality on Cortina Rancheria may result from local factors, such as recharge from stream channels, proximity to saline springs, and topographic effects on rainfall recharge. Ground-water quality on the rancheria may also show significant seasonal variations. Seasonal waterquality variations for nearby areas indicate that ground-water quality may be better in winter and spring than in late summer and autumn, when all of the samples shown in table 3 were collected. Rancheria residents have in fact noticed that water from the drilled well tastes better during the rainy winter season than during the dry summer season (Mary Norton, Cortina wintun tribal chairperson, oral commun., July 1986).

Because of the spatial and temporal variability of ground-water quality, it is difficult to determine accurately the quantity of fresh ground water potentially available on the rancheria. On the other hand, this variability offers the possibility of (1) storing high-quality winter water for use in summer or (2) finding localized pockets of high-quality ground water.

\section{DATA-COLLECTION PLAN}

The information presented in the preceding sections is insufficient to determine accurately the potential quantity, quality, and reliability of a local water supply for Cortina Rancheria. Additional data collected over a period of 1 to 2 years would make possible a greatly improved assessment of local water resources. Additional information also is needed to plan an expanded water supply, which might include additional wells, diversions from Canyon Creek or springs $B$ and $C$, surface impoundments, or artificial groundwater recharge. The following data-collection and analysis tasks collectively would provide the information needed for resource assessment and preliminary engineering design.

Task 1.--The first task would be to seal off temporarily the bottom half or three-quarters of the drilled well and test the upper part for yield and water quality. The well could be sealed with an inflatable packer. A recent study concluded that water in the well is of poor quality because the well was drilled too deep and draws much of its water from the Cortina Formation (Gasch and Associates, 1982). The packed-off well would yield less than its present capacity of $15 \mathrm{gal} / \mathrm{min}$, and it might go dry in the summer. The quality of water produced, however, would probably be much better. Transmissivity of the upper part could also be measured using a Hvorslev aquifer test, which is well suited for formations of low permeability (Freeze and Cherry, 1979).

Task 2.--The next task would be to install a temporary stream gage on Canyon Creek. Exposed bedrock in the stream channel throughout much of the reach between spring $A$ and the road crossing would ensure channel stability at all flow magnitudes. At an appropriate site, a bubble gage would be installed to record water depth at intervals no greater than 15 minutes. A depthdischarge rating curve would be developed from manual discharge measurements made during periodic site visits. The rating curve would be used to calculate discharge for all stage measurements during the study period. 
Task 3.--The third task would be to measure discharge at springs $A, B$, and C. During summer, flow consists entirely of spring discharge, and it can be measured with a Parshall flume or bucket and stopwatch. During periods of additional flow from surface runoff, spring discharge could be calculated by measuring the increase in streamflow between points above and below the spring. Current meters may not be sufficiently accurate to measure the increase if spring discharge is less than 5 percent of total streamflow. A more accurate method may be to measure the concentrations of conservative ions derived from the spring and calculate spring discharge using mixing models. Discharge would be measured every 1 to 2 months in summer and more frequently in winter.

Task 4.--The next task involves measuring daily rainfall and temperature. A raingage and maximum-minimum thermometer could be read on a daily basis by one of the rancheria residents, or measurements could be recorded automatically with a data logger.

Task 5.--The fifth task involves synthesizing a long-term record of flow in Canyon Creek using correlation or simulation. The correlation method would estimate historic flows by correlating flow in Canyon creek with flow in one or more nearby gaged streams, such as those noted in table 1 . The simulation method would reconstruct historic flows in Canyon Creek by simulating rainfallrunoff processes. For example, the climate data collected in task 4 could be used as input to the Precipitation-Runoff Modeling System (PRMS) developed by the U.S. Geological Survey. The purpose of synthesizing a long period of record would be to make a better estimate of the reliability of surface water as a potential source of supply.

Task 6.--An electromagnetic terrain conductivity (EM) survey of the eastern part of the rancheria would be the next task. EM surveys, which can distinguish vertical and horizontal salinity contrasts in ground water (MCNeill, 1980 and 1983), have been used successfully in seawater-intrusion studies (Stewart, 1982). In a study of the rancheria, EM would be used to distinguish fresh ground water in the Tehama Formation from underlying saline ground water. Proposed transects for the surveys are shown in figure 9. The long transect adjacent to the eastern boundary of the rancheria is on the thickest part of the Tehama Formation, where significant quantities of fresh ground water are most likely. This transect would also be oriented perpendicular to local drainage patterns, to determine whether recharge processes tend to create local bodies of fresh ground water beneath hills or adjacent to stream channels. Shorter transects oriented in an east-west direction would be used to map the thickness of fresh ground water as it pinches out against the saline ground water of the Cortina Formation to the west (fig. 3). The proposed transects (fig. 9) are aligned to include springs $B$ and $C$ and both existing wells. Water-quality measurements at these four points would be used to calibrate the EM measurements. The transects would be surveyed to correct for topographic effects when estimating the depth and thickness of the layer of fresh ground water.

Task 7.--The next task would be to drill shallow observation wells in three or four places near the eastern boundary of the rancheria. Ideally, these wells would reach exactly the bottom of the Tehama Formation, which probably occurs at depths less than 100 feet in most places. Wells need to be 


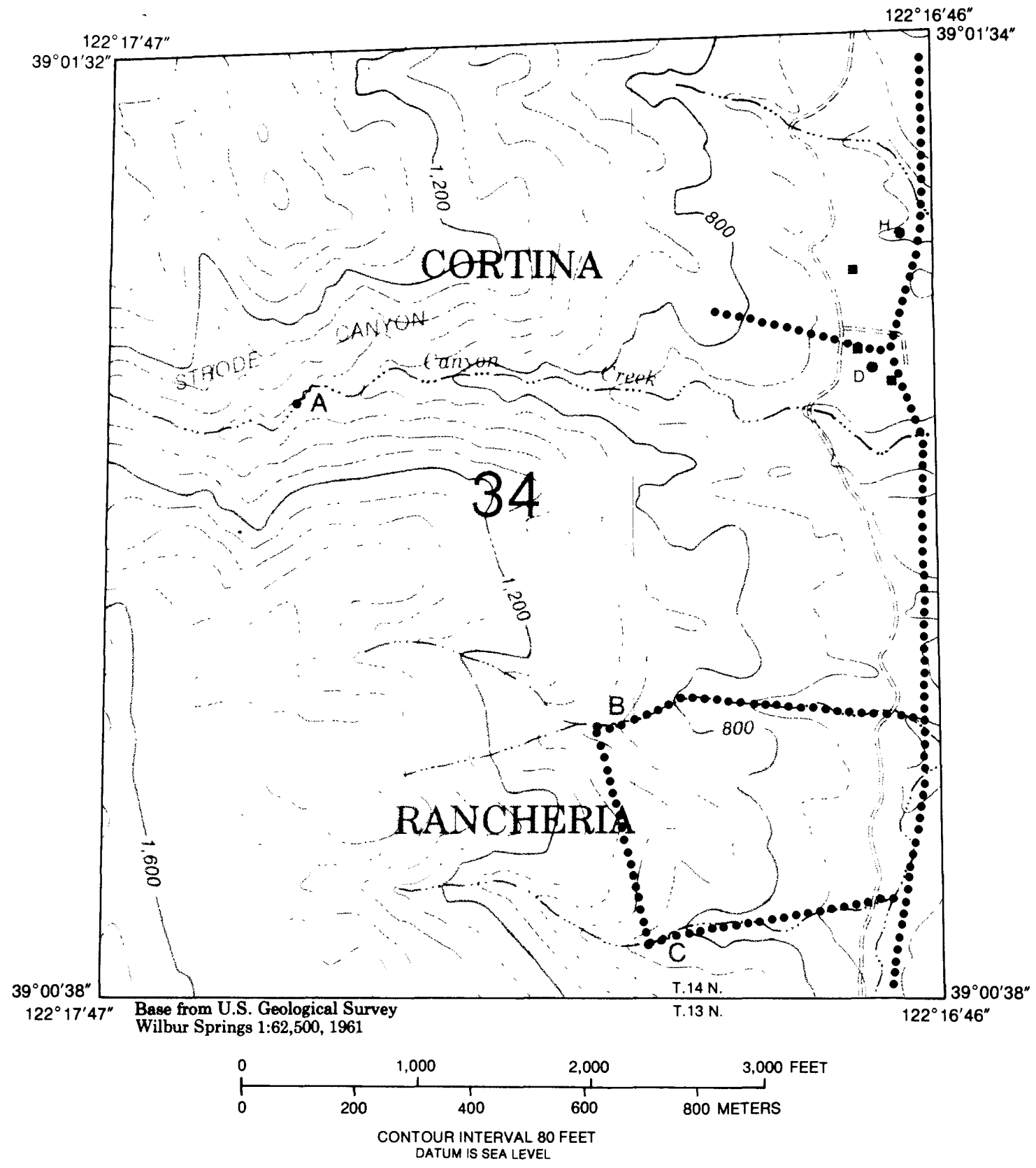

EXPLANATION

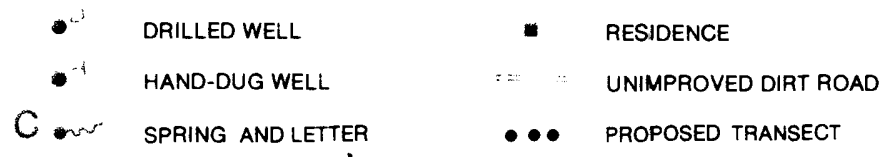

FIGURE 9. Locations of proposed electromagnetic terrain conductivity transects. 
located in the areas of freshest ground water, as identified by the EM measurements in task 6 . In order to measure the effects of streamflow events on ground-water levels, at least one well needs to be near Canyon Creek and one near the small unnamed creek that flows across the southeast corner of the rancheria (fig. 9). Because the observation wells would be shallow, they might be drilled with an auger rig rather than a more expensive mud-rotary rig.

Task 8.--The eighth task would be to monitor water levels in existing wells and in any new observation wells drilled in task 7. A continuous float recorder would be installed in at least one well near Canyon Creek to observe transient responses to streamflow events. Other wells would be measured monthly. These measurements would indicate seasonal changes in ground-water storage.

Task 9.--The final task would involve monitoring water quality in all wells, Canyon Creek, and springs A, B, and C. Specific conductance (SC) would be measured about every month. A resident of the rancheria could make these measurements. Water samples would be collected for analysis at least once and preferably twice during the winter rainy season. Samples would be analyzed for major ions, boron, and any additional constituents that are likely to exceed recommended levels for state of California (1985) drinking-water standards. Such analysis might include arsenic, barium, mercury, iron, manganese, lead, foaming agents, SC, nitrates, and dissolved solids.

\section{SUMMARY}

Cortina Rancheria occupies an area of $1 \mathrm{mi}^{2}$ on the side of Cortina Ridge in Colusa County near the western edge of the Sacramento Valley. The rancheria is underlain by Upper Cretaceous marine sediments of the Cortina Formation. In the eastern one-third of the rancheria, the Cortina Formation is overlain by the Tehama Formation, which consists mainly of fine-grained deposits laid down in a freshwater environment. Maximum thickness of the Tehama Formation at the rancheria is about 75 feet. Although the Tehama Formation generally contains freshwater, most wells penetrating it have low yields. A well 400 feet deep, which penetrates the Tehama and Cortina Formations, has a yield of only 15 $\mathrm{gal} / \mathrm{min}$.

The largest creek crossing Cortina Rancheria, referred to locally as Canyon Creek, has a drainage area of $3.1 \mathrm{mi}^{2}$. The creek generally flows only in winter and spring. A comparison with other streams along the west side of the Sacramento Valley indicates that the estimated mean annual flow in Canyon creek is about 720 acre-ft/yr. The estimated 100-year, 1-day peak flow is about $870 \mathrm{ft}^{3} / \mathrm{s}$. Dry years during which the creek never flows probably occur more frequently than once every 12 years. The three springs on the rancheria have discharges of generally less than $5 \mathrm{gal} / \mathrm{min}$.

The quality of ground and surface water on Cortina Rancheria is similar to that in other areas along the west side of the Sacramento valley. Water quality is generally poor because of high concentrations of dissolved solids derived from the marine sediments. Water-quality data for Thomes Creek, 60 miles north of the rancheria, indicate an inverse relation between stream 
discharge and the concentration of dissolved solids. Ground water from two wells and two springs on the rancheria was sampled in September 1986. Concentrations of dissolved solids ranged from 960 to $3,340 \mathrm{mg} / \mathrm{L}$, and concentrations of chloride ranged from 14 to $1,100 \mathrm{mg} / \mathrm{L}$. These data indicate significant spatial variability in ground-water quality. Water quality also varies significantly with time, as indicated by a comparison between these samples and samples collected in 1978 during a previous investigation (Ott Water Engineers, 1979).

Concentrations of barium, lead, manganese, iron, and foaming agents occasionally fail to meet state of California (1985) drinking-water standards. Concentrations of chloride and dissolved solids were above recommended levels in many samples. In addition, concentrations of boron, sodium, and chloride in some of the samples were great enough to restrict use of the water for irrigation.

A plan was developed to collect hydrologic information that would indicate more precisely the quantity and quality of surface and ground water at Cortina Rancheria. Principal features of the plan include monitoring of discharge and water quality in three springs and in Canyon Creek, electromagnetic terrain conductivity surveys, and monitoring of water levels and quality in two existing wells and several proposed test wells.

\section{REFERENCES CITED}

Bertoldi, G.L., 1976, Chemical quality of ground water in the Tehama-Colusa Canal service area, Sacramento Valley, California: U.S. Geological Survey Water-Resources Investigations Report 76-92, 44 p.

Bohn, H.L., McNeal, B.L., and O'Connor, G.A., 1979, Soil chemistry: New York, John Wiley, 329 p.

California, State of, 1985, California administrative code, Title 22. Social security, Division 4. Environmental Health, Chapter 15. Domestic water quality and monitoring: State of California, p. 1701-1722.

California Department of Water Resources, 1978, Evaluation of ground-water resources, Sacramento Valley: California Department of Water Resources Bulletin 118-6, $136 \mathrm{p}$.

----1981, Index to sources of hydrologic data: California Department of Water Resources Bulletin 230-81, $696 \mathrm{p}$.

Crippen, J.R., and Beall, R.M., 1970, A proposed streamflow data program for California: U.S. Geological Survey open-file report, $46 \mathrm{p}$.

Fogelman, R.P., Mullen, J.R., Shelton, W.F., and Simpson, R.G., 1983, Water resources data for California, water year 1982. Volume 4. Northern Central Valley basins and the Great Basin from Honey Lake basin to Oregon State line: U.S. Geological Survey Water-Data Report $\mathrm{CA}-82-4,319 \mathrm{p}$. 
Fogelman, R.P., Mullen, J.R., Shelton, W.F., and Grillo, D.A., 1984, Water resources data for California, water year 1983. Volume 4. Northern Central valley basins and the Great Basin from Honey Lake basin to Oregon State line: U.S. Geological Survey Water-Data Report CA-83-4, 291 p.

Fogelman, R.P., and Evenson, K.D., 1984, Water-resources monitoring in the Cottonwood Creek area, Shasta and Tehama Counties, California, 1982-83: U.S. Geological Survey Water-Resources Investigations Report 84-4187, $70 \mathrm{p}$.

Freeze, R.A., and Cherry, J.A., 1979, Groundwater: Englewood Cliffs, New Jersey, Prentice-Hall, 604 p.

Gasch and Associates, 1982, Cortina Rancheria water-well evaluation: Sacramento, Calif., Gasch and Associates, Inc., Sacramento Project GA8225, 4 p.

Hull, L.C., 1984, Geochemistry of ground water in the Sacramento Valley, California: U.S. Geological Survey Professional Paper 1401-B, 36 p.

Kirby, J.M., 1943, Upper Cretaceous stratigraphy of west side of Sacramento Valley south of Willows, Glenn County, California: American Association of Petroleum Geologist Bulletin, v. 27, no. 3, p. 279-305.

McNeill, J.D., 1980, Electromagnetic terrain conductivity measurements at low induction numbers: Mississauga, Ontario, Canada, Geonics, Ltd., Technical Note TN-6, 15 p.

---1983, EM34-3 survey interpretation techniques: Mississauga, Ontario, Canada, Geonics, Ltd., Technical Note TN-8, 7 p.

Mullen, J.R., Shelton, W.F., Simpson, R.G., and Grillo, D.A., 1985, Water resources data for California, water year 1984. Volume 4. Northern Central Valley basins and the Great Basin from Honey Lake basin to Oregon State line: U.S. Geological Survey Water-Data Report CA-84-4, 277 p.

----1987, Water resources data for California, water year 1985. Volume 4. Northern Central Valley basins and the Great Basin from Honey Lake basin to Oregon State line: U.S. Geological Survey Water-Data Report $\mathrm{CA}-85-4,289 \mathrm{p}$.

Olmsted, F.H., and Davis, G.H., 1961, Geologic features and ground-water storage capacity of the Sacramento Valley, California: U.S. Geological Survey Water-Supply Paper 1497, 242 p.

ott Water Engineers, 1979, Multi-purpose water resources investigation, Cortina Rancheria: Redding, California, ott Water Engineers, Inc., $30 \mathrm{p}$.

Rantz, S.E., 1969, Mean annual precipitation in the California region: U.S. Geological Survey open-file report, 2 sheets.

Rich, E.I., 1971, Geology of the Wilbur Springs quadrangle, Colusa and Lake Counties, California: U.S. Geological Survey Miscellaneous Geologic Investigations Map I-538, scale $1: 48,000$.

Stewart, M.T., 1982, Evaluation of electromagnetic methods for rapid mapping of salt-water interfaces in coastal aquifers: Groundwater, v. 20, no. 4, p. 538-545.

U.S. Bureau of Reclamation, 1958, Central Valley project, Sacramento River division, Yolo-Zamora unit, geology and ground-water resources appendix: U.S. Bureau of Reclamation, 50 p. 
U.S. Geological Survey, 1942-70, Surface-water supply of the United States, Part 11. Pacific slope basins in California: U.S. Geological Survey Water-Supply Papers 961, 981, 1011, 1041, 1061, 1091, 1121, 1151, 1181, $1215,1245,1285,1345,1395,1445,1515,1565,1635,1715,1928,1929$, $1930,1931,2128,2129,2130,2131$, various pagination.

U.S. Geological Survey, 1971-74, water resources data for California, water years 1971-74, Part 1, volume 2. Northern Great Basin and Central Valley: U.S. Geological Survey Water Data Reports CA-71-2 through CA-74-2, published annually.

1976-82, Water resources data, California, water years 1975-81, volume 4, Northern Central Valley basins and the Great Basin from Honey Lake basin to Oregon State line: U.S. Geological Survey Water-Data Reports CA-75-4 through CA-81-4, published annually. 